\title{
Review Article \\ Eating Behaviours and Body Weight Concerns among Adolescent Girls
}

\author{
Nadira Mallick, ${ }^{1}$ Subha Ray, ${ }^{1}$ and Susmita Mukhopadhyay ${ }^{2}$ \\ ${ }^{1}$ Department of Anthropology, University of Calcutta, 35 Ballygunge Circular Road, Kolkata 700 019, India \\ ${ }^{2}$ Biological Anthropology Unit, Indian Statistical Institute, 203 B.T. Road, Kolkata 108, India
}

Correspondence should be addressed to Nadira Mallick; r09mullick@gmail.com

Received 1 June 2014; Accepted 3 July 2014; Published 16 July 2014

Academic Editor: Julio Diaz

Copyright (c) 2014 Nadira Mallick et al. This is an open access article distributed under the Creative Commons Attribution License, which permits unrestricted use, distribution, and reproduction in any medium, provided the original work is properly cited.

This paper presents a global review of research done on adolescent eating behaviours and food choices and the probable factors underlying it. Worldwide adolescent girls tend to develop moderate to high level of disordered eating behaviour as a result of their excessive concern with body weight or obsession with thinness. The objective of the review is to understand the concerns over body weight and the current eating patterns of adolescent girls in the developed and developing countries.

\section{Introduction}

Adolescent eating behaviour is a function of individual and environmental influences [1]. Individual influences are psychological as well as biological, whereas, environmental influences include immediate social environments such as family, friend, and peer networks and other factors such as school meals and fast food outlets. In addition, another important factor is social system or macrosystem which includes mass media, marketing and advertising, social and cultural norms of the society [1]. Adolescent girls in particular, because of their excessive concern with body weight or obsession with thinness, are reported with moderate level of disordered eating behaviours [2]. Disordered eating behaviours refer to many disturbed eating patterns [3] which affect the nutritional status of adolescent girls [4]. The literature shows that adolescent girls are more prone to adopt various forms of eating behaviours than boys $[5,6]$, because they become preoccupied with and sensitive to their changing body size, shape, and physical appearance. This growing concern has led many of them to adopt dietary modifications that potentially throw serious threat on psychosocial development, nutritional status, and development of eating disorder. A number of factors like family environment [7-9], peer pressure [10$12]$, media habits $[13,14]$, concern over body image [15-17], sociocultural and economic context $[7,16,18]$, gender $[6]$, and age [19] make them feel dissatisfied with their body shape and weight.

Many studies have found that adolescent girls are interested in losing weight and more than $40 \%$ have even tried to lose weight due to concern over their body weight [20, 21]. A report of Youth Risk Behavioural Surveillance System (YRBSS) showed that more than $11 \%$ of high school girls in the United States reported taking diet pills, powders, or liquids to lose weight [22]. The data of this study also revealed that about $8 \%$ of the girls reported vomit their food after having it in the past month.

Study reports from USA and Europe suggested that the prevalence of disordered eating behaviours is increasing in western countries [23]. Disordered eating behaviours are associated with a number of harmful behaviours such as smoking, alcohol consumption, drug use, and suicide [24, 25] as well as physical and psychosocial consequences like poorer dietary quality [26, 27], depressive symptoms [28], weight gain and onset of obesity $[29,30]$, and finally the onset of eating disorders [31].

Obesity and eating disorder among adolescents are of serious public health concern owing to their high prevalence and adverse influence on psychological $[32,33]$ and physical health $[34,35]$. The prevalence of overweight [body mass index $(\mathrm{BMI})>95$ th percentile for age and sex] based on Centre for Disease Control and Prevention Growth charts 
[36] among children and adolescents has increased steadily over the past three decades. Currently, 15\% of youth aged 619 years are found to be overweight [37]. On the other hand, eating disorders like anorexia nervosa, bulimia nervosa, and binge eating affect a much small percentage of adolescent population (1-3\%) but are of great concern given their serious health consequences [3]. Another form of eating disorder called eating disorder not otherwise specified (EDNOS) affects much larger segment of adolescent population, with prevalence estimates as high as $15 \%$ [38]. Eating habits of adolescents, in general, are in process of changing from more traditional to more westernized one. Yannakoulia et al. [39] observed that eating behaviours like skipping meals, snacking, eating away from home, consumption of fast food, and following alternative dietary patterns (in terms of dieting) are the common eating behaviours of Greek adolescents. This type of eating habits may lead to nutritional deficiency during adolescence $[40,41]$ which may have long term consequences such as delayed sexual maturation and lower final adult height [42].

The aim of this review is to understand the current eating patterns and body weight concerns among adolescent girls in global and Indian context. Secondly, an attempt has been made to explore those factors influencing eating behaviours and body weight concerns.

\section{Western Scenario}

In western countries thin body is the most preferred body shape [43]. However, exceptions observed in certain ethnic groups [44]. Thinness is a symbol of beauty, success, control, and sexual attractiveness, while obesity represents laziness, self-indulgence, and lack of willpower [45]. To achieve thin body image, adolescent girls of western countries often remain engaged with their body weight and shape [46]. They may even deny the requirement of important nutritional components in their body when they need it most [47]. For example, in the United States, Killen et al. [48] found that $11 \%$ of female adolescents regularly vomit their food after having it and $13 \%$ of them reported some form of purging behaviours like use of laxatives or diuretics for body weight control due to excessive concern over body weight. A Minnesota schoolbased survey suggested an association between dieting and later onset of obesity and eating disorders [30]. Another study carried out in Minnesota revealed that $56 \%$ of 9 th grade females and $28 \%$ of 9 th grade males reported disordered eating behaviours such as fasting, vomiting, or binge eating. These behaviours were found to be high among both 12th grade females and males [49]. In Europe, study reported that adolescent who practiced disordered eating such as dieting had less self-esteem compared to those who practiced normal eating [50]. Many studies carried out in Australia also showed the existence of disordered eating behaviours and unhealthy weight reduction practices among adolescent girls $[46,47,51,52]$. Both young and older adolescent girls reported significantly more disordered eating behaviours than their male counterparts of these two age groups $[19,53]$. Study carried out in America found that rates of disordered eating were highest among overweight and obese youth school students [19, 54, 55]. Wichstrom [56] found that perceived obesity is associated with depression and unstable self-perceptions among general adolescent population of Norway.

\section{Situation in Nonwestern Countries}

The western concept of thinness as a symbol of beauty and attractiveness is not confined to western countries anymore. The western concept of beauty and attractiveness in thinness is diffusing among the youth of some nonwestern countries like Philippines [57] and Thailand [58]. Lorenzo et al. [59] found in his study that disordered eating attitude and behaviour among adolescents are becoming a significant problem in Philippines. Studies on Chinese population show that adolescents who were concerned about their body weight suffered from depression [60] and high level of psychological distress [61]. A study from Singapore reported that about $7.4 \%$ of women are at risk of developing eating disorder [62]. Study concluded that western media might have a negative impact upon body image and eating pattern among women in Singapore.

Taiwan and Japanese females show higher incidence of dieting [63]. Chang et al. [64] found that about $17.11 \%$ of Taiwanese adolescent girls reported disordered eating behaviours. Results of the same study showed that intake of energy, protein, carbohydrate, zinc, and vitamins B6 and B12 was significantly lower in those adolescent girls who followed disordered eating behaviours compared to those who showed normal eating behaviours. The adolescent girls who followed disordered eating consumed higher amount of fiber rich foods than those who did not. The study concluded by saying that disordered eating behaviours markedly affect nutritional status of these adolescent girls.

Internationalization of thin body weight and mass media play an important role in the development of disordered eating behaviours among Arabian adolescents living in the United Arab Emirates [65]. Study reported that about $66 \%$ of adolescents perceived themselves as overweight and desired to be thin. Study also revealed that about $78 \%$ of adolescents expressed dissatisfaction with their current body weight and attempted to reduce it through restricting food intake, avoidance of certain food groups, excessive exercise, and selfinduced vomiting. Such types of eating behaviours among adolescents were found in past studies, carried out in Saudi Arab and Oman $[66,67]$. Another west Asian country, Israel, showed higher rate of abnormal eating attitudes (as reflected by high EAT-26 score) among adolescents from both Jewish and Arab origins $[68,69]$.

Adolescent girls from south region of Asia showed a similar trend as that found in the other parts of Asia. Sharma [70] found in his study that consumption of fast food was preferred by more than two-third of the school students aged 9-11 years under the influence of television advertisements. Study also showed that consumption of traditional food items such as pulses, green leafy vegetables, fruits, and milk was found to be low among the study group. 


\section{The Indian Picture}

In India, adolescents (from 10 to 19 years) accounted for $22.8 \%$ of the population [71] and they face a series of serious nutritional challenges that are affecting not only their growth and development but also their livelihood as adults. On the other hand, presently Indians are experiencing nutritional and lifestyle transition due to globalisation. Many of the adolescent girls modify their normal dietary pattern and follow disturbed eating behaviours [72] and these also affect their nutritional status [73]. Very few studies have been done in India considering eating behaviour and its impact on nutritional status of adolescent girls.

4.1. Eating Behaviours in Various Regions of India. In north India about $0.4 \%$ of college girls, residing in foot hills regions of Himalaya, practiced binge eating (a form of disordered eating behaviour) during festive occasions only to check overeating [74]. In this study, none of the girls reported taking any diet pills, laxatives, or diuretics. Mishra and Mukhopadhyay [72] in their study on Sikkimese adolescent reported that girls often opted for skipping of meals to control their body weight. Some of them reported the habit of snacking between main meals. The same study revealed that girls who remained dissatisfied with their body weight were more inclined to diet. In Delhi, weight concern and dissatisfaction over body weight were prevalent among underweight as well as overweight adolescent girls [73]. Eating behaviours like skipping meals, eating out, and snacking were common among these adolescent girls. Although girls had enough knowledge regarding nutritional deficiency, yet they did not/could not follow normal eating behaviours. As a result their diets remain deficient with energy, protein, iron, niacin, vitamin $\mathrm{A}$, and fibre. The study further revealed that adolescent girls with unhealthy eating behaviours showed lack of interest in their educational assignment than girls with good eating habits. Nutritional disorders among another group of adolescent girls in Delhi indicated that individuals of both high and low socioeconomic groups suffered from anemia [75].

A form of distress and disorder in eating habits and attitude towards the body weight had been reported among the adolescents in Chennai, the southern part of India [76]. Later study by Srinivasan et al. [77] showed that very few adolescents (11\%) developed a milder form of eating disorder with the fear of fatness. Augustine and Poojara [78] reported that more than half of the adolescent girls residing in Ernakulam wanted to lose body weight. Results showed that the weight loss plans among the study groups included exercise (21\%), followed by meal skipping (20\%), starvation $(16 \%)$, binge eating $(6 \%)$, and consumption of diet pills (2\%), and the most commonly skipped meal was breakfast. Latha et al. [79] studied female adolescent college students (aged 16 to 21 years) at Udipi, Karnataka. The result showed that more than $80 \%$ of the girls wanted to become slim because they remain too much busy on thinking about their appearance, body weight, and shape. In this study most of the study participants showed high scores on anxiety, somatic symptoms, and social dysfunction subscales. This indicates that adolescence is the phase of confusion, uncertainties, and instability. In 2009, two cases of anorexia nervosa (a type of eating disorder) were found by Mendhekar et al. [80]. Both of them were middle class urban adolescent school going girls, who experienced marked weight reduction (BMI > 11.5) and other symptoms of anorexia nervosa. Study showed that factors like parental influence, peer pressure, media habits, and preoccupation with thinness were not the only factors responsible for this disease. The author expressed that clinical symptoms of anorexia nervosa in India may be similar in nature to those in western countries but the psychosocial development and psychodynamic aspects may be different in India.

\section{Factors Influencing Eating Behaviours and Body Weight Concerns}

5.1. Family Environment and Peer Pressure. Sometimes a child's eating behaviour is influenced by their parents' attitude $[8,9]$. Many studies reported that parents, particularly mothers, have a considerable influence on their children's eating and dieting patterns, because of their presumed central role in acting out the nature and importance of thinness and the gender-stereotyped nature of dieting itself $[8,81,82]$. In some cases, parents influence their child to lose weight without imparting the proper knowledge of losing weight. Hence, the children tend to follow unhealthy means while losing weight [83], while other studies showed that the parents did influence their children's eating habits by imparting proper knowledge $[84,85]$.

Peer influence and group conformity can be considered as important determinants in food acceptability and selection. Baker et al. [11] examined eating behaviours in a sample of 279 adolescents from a midsized catholic girls' school and a large public school of US and showed that adolescents were less likely to have a positive attitude or intention about healthy eating and activity if their parents and peer group do not perceive these behaviours as important in life. Another study carried out among Costa Rican adolescents demonstrated direct impact of peer influence on intake of foods containing saturated fat [10]. Favor [12] found that a teenage girl may eat nothing but a green lettuce salad for lunch following her friend, even though she will become hungry later on.

5.2. Sociocultural and Economic Context. Disordered eating is found among adolescent girls of higher socioeconomic status [7]. On the other hand, Jones et al. [16] observed that socioeconomic status (SES) was not significantly associated with disturbed eating behaviours in a school-based study in Ontario. Similar result has been found by Rogers et al. [86] among another group of adolescents and this study reflected the pervasive influence of the media on all SES groups. The cultural context, especially ethnicity and religion, can also influence the development of disordered eating and body weight concern. Studies indicated that black females had larger body size ideals in both USA [44] and SubSaharan Africa [87] than their white counterparts and that they tend to be more satisfied with their actual body size than white females [44]. While an ideal for heavier body image 
may protect black females from developing anorexic-type eating disorders [88], it may increase their risk of overweight [89]. Abraham and Birmingham [18] found that Muslim adolescent girls and adult women have a higher prevalence of elevated Eating Attitude Test scores compared to nonMuslim.

5.3. Concern over Body Image, Gender, and Age. A person's body image is influenced by his/her belief and attitude as well as societal standards of appearance and attractiveness [79]. Females show greater discrepancy between their perceived body size and their ideal body size compared to males [90]. Moreover, concern over body image is more common among adolescent females than the other age groups [91] and they preferred to be identified as overweight than the males [92].

A report of the 2013 Vermont Youth Risk Behavior Survey [93] has shown that a majority of the students (both male and female) perceived themselves to be normal weight. Females were significantly more likely to consider themselves as overweight compared to males. As a result, two-third of female and one-third of male students seriously tried to lose their body weight.

A good number of studies revealed that girls are less satisfied with their body image and have higher rates of body dissatisfaction over weight than boys [7, 15, 16, 90, 94]. Sometimes society puts pressure on women to conform to the cultural ideal for size and shape [95]. This cultural ideal has changed through mass media towards becoming increasingly thin among females in USA [96]. Many studies revealed that younger girls are significantly less likely to engage in disordered eating behaviour than older ones $[16,19,53]$.

5.4. Eating Away from Home. During adolescence teens spend less time with family and more time with friends. This reflects their independent nature at the juncture of boyhood and adulthood. Washi and Ageib [97] showed that most of the adolescents in Jeddah, Saudi Arabia, prefer outof-home food. Results of their study indicated that more than $80 \%$ of the participants depend upon fast food rather than home-made food and $73 \%$ of them eat at fast food restaurants. A survey conducted on 379 UK adolescents (11 yrs to 12 yrs of age) revealed that eating outside the home accounted for about $30 \%$ of daily energy intake [98]. The study concluded that food consumed at home had better density of micronutrient than food consumed outside. The study also revealed that meals taken during tiffin hours at school are rich in fats but contained less protein, nonstarch polysaccharide, iron, and retinol equivalents.

5.5. Media Habits. Among all factors, media presentation of thin image is a major contributor to current high incidence of body dissatisfaction and eating disorders in women [14, $83,99,100]$. One naturalistic experiment conducted in Fiji provides strong evidence to support the hypothesis that the media has a significant role in the development of body dissatisfaction and eating disorder symptoms [17]. Fiji was a relatively media-native society with little western mass media influence. In this study, the eating attitudes and behaviours of Fijian adolescent girls were measured prior to the introduction of regional television and after the prolonged exposure to television viewing. The results indicated that following the television exposure, these adolescent girls exhibit a significant increase in disordered eating attitudes and behaviours. Becker et al. [101] showed in their study on Fijian adolescent girls that exposure to social network media was associated with eating pathology among the girls aged 15 to 20 years.

Television advertising and soap operas generally represent the heroine as slim, young, and beautiful. Adolescent girls are very much influenced by watching these advertisements on television and mostly they try to keep their body slim [102]. Fashion magazines have become increasingly popular among majority of the adolescent girls [103]. Some researchers showed significant association between body dissatisfaction among teenage girls and their exposure to thin models in the media $[104,105]$. For example, girls who read fashion magazines often compared themselves with the models in the television advertisements and the magazine articles, resulting in more negative feelings about their own body shape [106-109]. Field et al. [13] found in their study that $69 \%$ of the girls from US reported that pictures published in magazines influence their idea of perfect body shape and $47 \%$ reported losing weight because of these pictures. Study also revealed that females exercise and diet more in response to fashion magazine images. Borzekowski et al. [110] reported that there are many articles available in more than 100 proanorexia websites that not only encourage disordered eating but give specific advice on purging, severe restriction on calorie intake, and excessive exercise. The media (both the printed and the electronic) play significant role in eating behaviours and body image concern of the adolescent girls and it may contribute to the development of eating disorders among them [111].

\section{Conclusion}

6.1. Main Findings of This Review. Following are the main findings of this review.

(i) The eating behaviours like dieting, fasting, skipping meals, and consumption of fast food are found to be high among adolescent girls both from western and nonwestern countries. This whole range of behaviours may develop physical and mental health risk to the adolescents.

(ii) Adolescents from western countries follow more disturbed eating pattern and show excessive concern over body weight compared to adolescents from nonwestern countries.

(iii) This review identified a good number of factors influencing the body weight concern and eating behaviour of adolescent girls. Studies also identified that mass media, peer pressure, and culture are the main contributors among all.

The cultural context in India has changed in the past few years [77]. A shift towards the concept of thin body 
image is occurring among girls of urban areas through mass media. A majority of girls are interested in attaining thin body image which sometimes leads to dissatisfaction over body weight. Dissatisfaction over body weight provokes the development of body weight concerns and disordered eating behaviours among these adolescent girls and disordered eating behaviours may induce increased risk of eating disorder during later period. This is further being governed by macrolevel global economic forces. For example, India is passing through a transitional phase in dietary pattern due to influence of economic changes, rapid urbanization, women's participation in workforce, and globalization. This transition is marked by a shift from traditional diet to modern western diet which is usually more varied in nature and more preprocessed food, more food of animal origin, and more added sugar and fat $[112,113]$. This kind of dietary practices is found to be high among the adolescents due to its vast availability in the market and another reason may be the market influence of popular fast foods promoted through advertising by mass media [114]. Increase in women's participation in workforce on a large scale restrained working mothers from spending sufficient time with their families. To make up for this gap, they sometimes purchase prepared foods and packet foods from restaurants or grocery stores [115], which can also change the pattern of food consumption among the children. Changes in the dietary pattern might lead to a shift from cereal based diet towards high fat and high sugar rich food items that might lead to obesity and other metabolic disorders.

Therefore, future research should be directed to understanding present eating behaviours and body weight concerns, health risk, and associated factors among adolescent girls in India. Such studies would play an important role in the assessment of current nutritional status of adolescent girls and may help develop meaningful/effective nutritional intervention program by the government.

\section{Conflict of Interests}

The authors have no conflict of interests regarding this paper.

\section{Acknowledgment}

This research was supported by a grant from the University of Calcutta.

\section{References}

[1] M. Story, D. Neumark-Sztainer, and S. French, "Individual and environmental influences on adolescent eating behaviors.," Journal of the American Dietetic Association, vol. 102, no. 3, pp. S40-S51, 2002.

[2] H. N. Madanat, R. Lindsay, and T. Campbell, "Young urban women and the nutrition transition in Jordan," Public Health Nutrition, vol. 14, no. 4, pp. 599-604, 2011.

[3] American Psychiatric Association, Diagnostic and Statistical Manual of Mental Disorders: DSM-IV, American Psychiatric Association, Washington, DC, USA, 4th edition, 1994.
[4] M. Tsai, Y. Chang, P. Lien, and Y. Wong, "Survey on eating disorders related thoughts, behaviors and dietary intake in female junior high school students in Taiwan," Asia Pacific Journal of Clinical Nutrition, vol. 20, no. 2, pp. 196-205, 2011.

[5] E. C. Weiss, D. A. Galuska, L. K. Khan, and M. K. Serdula, "Weight-control practices among US adults, 2001-2002," The American Journal of Preventive Medicine, vol. 31, no. 1, pp. 18$24,2006$.

[6] C. Costa, E. Ramos, M. Severo, H. Barros, and C. Lopes, "Determinants of eating disorders symptomatology in Portuguese adolescents," Archives of Pediatrics and Adolescent Medicine, vol. 162, no. 12, pp. 1126-1132, 2008.

[7] D. Neumark-Sztainer, M. E. Eisenberg, J. A. Fulkerson, M. Story, and N. I. Larson, "Family meals and disordered eating in adolescents: longitudinal findings from Project EAT," Archives of Pediatrics and Adolescent Medicine, vol. 162, no. 1, pp. 17-22, 2008.

[8] A. J. Hill and J. A. Franklin, "Mothers, daughters and dieting: investigating the transmission of weight control," British Journal of Clinical Psychology, vol. 37, no. 1, pp. 3-13, 1998.

[9] L. Smolak, M. P. Levine, and F. Schermer, "Parental input and weight concerns among elementary school children," International Journal of Eating Disorders, vol. 25, pp. 263-271, 1999.

[10] R. Monge-Rojas, H. P. Nuñez, C. Garita, and M. Chen-Mok, "Psychosocial aspects of Costa Rican adolescents' eating and physical activity patterns," Journal of Adolescent Health, vol. 31, no. 2, pp. 212-219, 2002.

[11] C. W. Baker, T. D. Little, and K. D. Brownell, "Predicting adolescent eating and activity behaviors: the role of social norms and personal agency," Health Psychology, vol. 22, no. 2, pp. 189198, 2003.

[12] L. J. Favor, Food as Foe: Nutrition and Eating Disorders, Courtesy of the National Academic Press, Washington, DC, USA, 2007.

[13] A. E. Field, C. A. Camargo Jr., C. B. Taylor, C. S. Berkey, and G. A. Colditz, "Relation of peer and media influences to the development of purging behaviors among preadolescent and adolescent girls," Archives of Pediatrics and Adolescent Medicine, vol. 153, no. 11, pp. 1184-1189, 1999.

[14] T. F. Cash and T. Pruzinsky, Body Image: A Handbook of Theory, Research and Clinical Practice, The Guildford Press, London, UK, 1st edition, 2004.

[15] J. Demarest and R. Allen, "Body image: gender, ethnic, and age differences," Journal of Social Psychology, vol. 140, no. 4, pp. 465$472,2000$.

[16] J. M. Jones, S. Bennett, M. P. Olmsted, M. L. Lawson, and G. Rodin, "Disordered eating attitudes and behaviours in teenaged girls: a school-based study," CMAJ, vol. 165, no. 5, pp. 547-552, 2001.

[17] A. E. Becker, R. A. Burwell, S. E. Gilman, D. B. Herzog, and P. Hamburg, "Eating behaviours and attitudes following prolonged exposure to television among ethnic Fijian adolescent girls," British Journal of Psychiatry, vol. 180, pp. 509-514, 2002.

[18] N. K. Abraham and C. L. Birmingham, "Is there evidence that religion is a risk factor for eating disorders?" Eating and Weight Disorders, vol. 13, no. 4, pp. e75-e78, 2008.

[19] D. Neumark-Sztainer and P. J. Hannan, "Weight-related behaviors among adolescent girls and boys: results from a national survey," Archives of Pediatrics and Adolescent Medicine, vol. 154, no. 6 , pp. 569-577, 2000.

[20] J. Wardle and L. Marsland, "Adolescent concerns about weight and eating; a social-developmental perspective," Journal of Psychosomatic Research, vol. 34, no. 4, pp. 377-391, 1990. 
[21] L. Kann, C. W. Warren, W. A. Harris et al., "Youth Risk Behavior Surveillance-United States, 1995," Journal of School Health, vol. 66, no. 10, pp. 365-377, 1996.

[22] J. A. Grunbaum, L. Kann, S. Kinchen et al., "Youth risk behavior surveillance: United States, 2003 (Abridged)," Journal of School Health, vol. 74, no. 8, pp. 307-324, 2004.

[23] J. M. Eagles, M. I. Johnston, D. Hunter, M. Lobban, and H. R. Millar, "Increasing incidence of anorexia nervosa in the female population of northeast Scotland," American Journal of Psychiatry, vol. 152, no. 9, pp. 1266-1271, 1995.

[24] H. E. Ross and F. Ivis, "Binge eating and substance use among male and female adolescents," International Journal of Eating Disorders, vol. 26, pp. 245-260, 1999.

[25] D. Neumark-Sztainer, M. Story, L. B. Dixon, and D. M. Murray, "Adolescents engaging in unhealthy weight control behaviors: are they at risk for other health-comprising behaviors?" American Journal of Public Health, vol. 88, no. 6, pp. 952-955, 1998.

[26] H. Crawley and R. Shergill-Bonner, "The nutrient and food intakes of 16-17 year old female dieters in the UK," Journal of Human Nutrition and Dietetics, vol. 8, no. 1, pp. 25-34, 1995.

[27] D. Neumark-Sztainer, M. Wall, M. Story, and J. A. Fulkerson, "Are family meal patterns associated with disordered eating behaviors among adolescents?" Journal of Adolescent Health, vol. 35, no. 5, pp. 350-359, 2004.

[28] E. Stice, "A prospective test of the dual-pathway model of bulimic pathology: mediating effects of dieting and negative affect," Journal of Abnormal Psychology, vol. 110, no. 1, pp. 124135, 2001.

[29] E. Stice, K. Presnell, L. Groesz, and H. Shaw, "Effects of a weight maintenance diet on bulimic symptoms in adolescent girls: an experimental test of the dietary restraint theory," Health Psychology, vol. 24, no. 4, pp. 402-412, 2005.

[30] D. Neumark-Sztainer, S. J. Paxton, P. J. Hannan, J. Haines, and M. Story, "Does Body Satisfaction Matter? Five-year Longitudinal Associations between Body Satisfaction and Health Behaviors in Adolescent Females and Males," Journal of Adolescent Health, vol. 39, no. 2, pp. 244-251, 2006.

[31] G. C. Patton, R. Selzer, C. Coffey, J. B. Carlin, and R. Wolfe, "Onset of adolescent eating disorders: population based cohort study over 3 years," British Medical Journal, vol. 318, pp. 765-768, 1999.

[32] C. C. Strauss, "Personal and interpersonal characteristics associated with childhood obesity," Journal of Pediatric Psychology, vol. 10, no. 3, pp. 337-343, 1985.

[33] J. G. Johnson, P. Cohen, S. Kasen, and J. S. Brook, "Childhood adversities associated with risk for eating disorders or weight problems during adolescence or early adulthood," The American Journal of Psychiatry, vol. 159, no. 3, pp. 394-400, 2002.

[34] A. Fagot-Campagna, D. J. Pettitt, M. M. Engelgau et al., "Type 2 diabetes among North American children and adolescents: an epidemiologic review and a public health perspective," Journal of Pediatrics, vol. 136, no. 5, pp. 664-672, 2000.

[35] S. Zipfel, B. Löwe, D. L. Reas, H. Deter, and W. Herzog, "Longterm prognosis in anorexia nervosa: lessons from a 21-year follow-up study,' The Lancet, vol. 355, no. 9205, pp. 721-722, 2000.

[36] R. J. Kuczmarski, C. L. Ogden, S. S. Guo et al., "CDC growth charts for the United States: methods and development," Vital and Health Statistics, vol. 11, pp. 1-190, 2002.

[37] C. L. Ogden, K. M. Flegal, M. D. Carroll, and C. L. Johnson, "Prevalence and trends in overweight among US children and adolescents, 1999-2000," The Journal of the American Medical Association, vol. 288, no. 14, pp. 1728-1732, 2002.

[38] E. Kjelsås, C. Bjørnstrøm, and K. G. Götestam, "Prevalence of eating disorders in female and male adolescents (14-15 years)," Eating Behaviors, vol. 5, no. 1, pp. 13-25, 2004.

[39] M. Yannakoulia, D. Karayiannis, M. Terzidou, A. Kokkevi, and L. S. Sidossis, "Nutrition-related habits of Greek adolescents," European Journal of Clinical Nutrition, vol. 58, no. 4, pp. 580586, 2004.

[40] T. A. Nicklas, L. Myers, C. Reger, B. Beech, and G. S. Berenson, "Impact of breakfast consumption on nutritional adequacy of the diets of young adults in Bogalusa, Louisiana: ethnic and gender contrasts," Journal of the American Dietetic Association, vol. 98, no. 12, pp. 1432-1438, 1998.

[41] P. Gleason and C. Suitor, "Children's diets in the mid-1990s: dietary intake and its relationship with school meal participation special nutrition programmes," Report no. CN-01-CD1, US Department of Agriculture, Food and Nutrition Service, Alexandria, Va, USA, 2001.

[42] R. Wahl, "Nutrition in the adolescent," Pediatric Annals, vol. 28, no. 2, pp. 107-111, 1999.

[43] I. Attie and J. Brooks-Gunn, "Devolopemental issues in the study of eating problems and disorders," in The Etiology of Bulimia Nervosa: The Individual and Familial Context, J. H. Crowther, D. L. Tennenbaum, S. E. Hobfoll, and M. A. P. Stevens, Eds., pp. 35-59, Hemisphere, Washington, DC, USA, 1992.

[44] E. Lynch, K. Liu, B. Spring, A. Hankinson, G. S. Wei, and P. Greenland, "Association of ethnicity and socioeconomic status with judgments of body size: the coronary artery risk development in young Adults (CARDIA) study," The American Journal of Epidemiology, vol. 165, no. 9, pp. 1055-1062, 2007.

[45] World Health Organization, "Obesity: Preventing and Managing the Global Epidemic," http://www.who.int/nutrition/ publications/obesity/WHO_TRS_894/en/.

[46] M. Grigg, J. Bowman, and S. Redman, "Disordered eating and unhealthy weight reduction practices among adolescent females," Preventive Medicine, vol. 25, no. 6, pp. 748-756, 1996.

[47] J. Polivy and C. P. Herman, "Dieting and binging. A causal analysis," The American Psychologist, vol. 40, no. 2, pp. 193-201, 1985.

[48] J. D. Killen, C. B. Taylor, M. J. Telch, K. E. Saylor, D. J. Maron, and T. N. Robinson, "Self-induced vomiting and laxative and diuretic use among teenagers. Precursors of the binge-purge syndrome?" Journal of the American Medical Association, vol. 255, no. 11, pp. 1447-1449, 1986.

[49] J. Croll, D. Neumark-Sztainer, M. Story, and M. Ireland, "Prevalence and risk and protective factors related to disordered eating behaviors among adolescents: relationship to gender and ethnicity," Journal of Adolescent Health, vol. 31, no. 2, pp. 166175, 2002.

[50] L. Peternel and A. Sujoldžić, "Adolescents eating behavior, body image and psychological well-being," Collegium Antropologicum, vol. 33, no. 1, pp. 205-212, 2009.

[51] S. J. Paxton, E. H. Wertheim, K. Gibbons, G. I. Szmukler, L. Hillier, and J. L. Petrovich, "Body image satisfaction, dieting beliefs, and weight loss behaviors in adolescent girls and boys," Journal of Youth and Adolescence, vol. 20, no. 3, pp. 361-379, 1991.

[52] E. H. Wertheim, S. J. Paxton, D. Maude, G. I. Szmukler, K. Gibbons, and L. Hiller, "Psychosocial predictors of weight loss behaviors and binge eating in adolescent girls and boys," 
International Journal of Eating Disorders, vol. 12, no. 2, pp. 151160, 1992.

[53] U. Berger, C. Schilke, and B. Strauß, "Weight concerns and dieting among 8 to 12-year-old children," PPmP Psychotherapie Psychosomatik Medizinische Psychologie, vol. 55, no. 7, pp. 331338, 2005.

[54] A. L. Toselli, S. Villani, A. M. Ferro, A. Verri, L. Cucurullo, and A. Marinoni, "Eating disorders and their correlates in high school adolescents of Northern Italy," Epidemiologia $e$ Psichiatria Sociale, vol. 14, no. 2, pp. 91-99, 2005.

[55] J. S. Vander Wal and M. H. Thelen, "Eating and body image concerns among obese and average-weight children," Addictive Behaviors, vol. 25, no. 5, pp. 775-778, 2000.

[56] L. Wichstrom, "Social, psychological and physical correlates of eating problems: a study of the general adolescent population in Norway," Psychological Medicine, vol. 25, no. 3, pp. 567-579, 1995.

[57] L. L. Farrales and G. E. Chapman, "Filipino women living in Canada: constructing meanings of body, food, and health," Health Care for Woman International, vol. 20, no. 2, pp. 179-194, 1999.

[58] P. S. Jennings, D. Forbes, B. McDermott, G. Hulse, and S. Juniper, "Eating disorder attitudes and psychopathology in Caucasian Australian, Asian Australian and Thai university students," Australian and New Zealand Journal of Psychiatry, vol. 40, no. 2, pp. 143-149, 2006.

[59] C. R. Lorenzo, P. W. Lavori, and J. D. Lock, "Eating attitudes in high school students in the Philippines: a preliminary study," Eating and Weight Disorders : EWD, vol. 7, no. 3, pp. 202-209, 2002.

[60] B. Xie, C. H. Liu, C. P. Chou et al., "Weight perception and psychological factors in Chinese adolescents," Journal of Adolescent Health, vol. 33, no. 3, pp. 202-210, 2003.

[61] Y. Luo, W. L. Parish, and E. O. Laumann, "A population-based study of body image concerns among urban Chinese adults," Body Image, vol. 2, no. 4, pp. 333-345, 2005.

[62] T. F. Ho, B. C. Tai, E. L. Lee, S. Cheng, and P. H. Liow, "Prevalence and profile of females at risk of eating disorders in Singapore," Singapore Medical Journal, vol. 47, no. 6, pp. 499503, 2006.

[63] L. S. Adair, "Dramatic rise in overweight and obesity in adult Filipino women and risk of hypertension," Obesity Research, vol. 12, no. 8, pp. 1335-1341, 2004.

[64] Y. Chang, W. Lin, and Y. Wong, "Survey on eating disorderrelated thoughts, behaviors, and their relationship with food intake and nutritional status in female high school students in Taiwan," Journal of the American College of Nutrition, vol. 30, no. 1, pp. 39-48, 2011.

[65] V. Eapen, A. A. Mabrouk, and S. Bin-Othman, "Disordered eating attitudes and symptomatology among adolescent girls in the United Arab Emirates," Eating Behaviors, vol. 7, no. 1, pp. 53-60, 2006.

[66] A. S. Al-Subaie, "Eating attitudes test in Arabic: Psychometric features and normative data," Saudi Medical Journal, vol. 19, no. 6, pp. 769-775, 1998.

[67] S. Al-Adawi, A. S. S. Dorvlo, D. T. Burke, S. Al-Bahlani, R. G. Martin, and S. Al-Ismaily, "Presence and severity of anorexia and bulimia among male and female omani and non-omani adolescents," Journal of the American Academy of Child and Adolescent Psychiatry, vol. 41, no. 9, pp. 1124-1130, 2002.
[68] A. Apter, M. Abu Shah, I. Iancu, H. Abramovitch, A. Weizman, and S. Tyano, "Cultural effects on eating attitudes in Israeli subpopulations and hospitalized anorectics," Genetic, Social, and General Psychology Monographs, vol. 120, no. 1, pp. 83-99, 1994.

[69] N. R. Maor, S. Sayag, R. Dahan, and D. Hermoni, "Eating attitudes among adolescents," Israel Medical Association Journal, vol. 8, no. 9, pp. 627-629, 2006.

[70] I. Sharma, "Trends in the intake of ready-to-eat food among urban school children in Nepal," SCN News, vol. 16, pp. 21-22, 1998.

[71] Working group report on Adolescents-of Planning Commission, 2013, http://www.planningcommission.nic.in/aboutus/ committee/wrkgrp/wg_adolcnts.pdf.

[72] S. K. Mishra and S. Mukhopadhyay, "Eating and weight concerns among Sikkimese adolescent girls and their biocultural correlates: An exploratory study," Public Health Nutrition, vol. 14, no. 5, pp. 853-859, 2010.

[73] R. Chugh and S. Puri, "Affluent adolescent girls of Delhi: eating and weight concerns," British Journal of Nutrition, vol. 86, no. 4, pp. 535-542, 2001.

[74] D. Bhugra, K. Bhui, and K. R. Gupta, "Bulimic disorders and sociocentric values in north india," Social Psychiatry and Psychiatric Epidemiology, vol. 35, no. 2, pp. 86-93, 2000.

[75] G. Kapoor and S. Aneja, "Nutritional disorders in adolescent girls," Indian Pediatrics, vol. 29, no. 8, pp. 969-973, 1992.

[76] T. N. Srinivasan, T. R. Suresh, V. Jayaram et al., "Eating disorders in India," Indian Journal of Psychiatry, vol. 37, pp. 26-30, 1995.

[77] T. N. Srinivasan, T. R. Suresh, and V. Jayaram, "Emergence of eating disorders in India. Study of eating distress syndrome and development of a screening questionnaire," International Journal of Social Psychiatry, vol. 44, no. 3, pp. 189-198, 1998.

[78] L. F. Augustine and R. H. Poojara, "Prevalane of obesity, weight perceptions and weight control practices among urban college going girls," Indian Journal of Community Medicine, vol. 28, no. 4, pp. 187-190, 2003.

[79] K. S. Latha, S. Hegde, S. M. Bhat, P. S. V. N. Sharma, and P. Rai, "Body image, self-esteem and depression in female adolescent college students," Journal of Indian Association for Child and Adolescent Mental Health, vol. 2, no. 3, pp. 78-84, 2006.

[80] D. N. Mendhekar, K. Arora, D. Lohia, A. Aggarwal, and R. C. Jiloha, "Anorexia nervosa: an Indian perspective," National Medical Journal of India, vol. 22, no. 4, pp. 181-182, 2009.

[81] H. Edmunds and A. J. Hill, "Dieting and the family context of eating in young adolescent children," International Journal of Eating Disorders, vol. 25, pp. 435-440, 1999.

[82] S. H. Thompson, A. C. Rafiroiu, and R. G. Sargent, "Examining gender, racial, and age differences in weight concern among third, fifth, eight, and elevent graders," Eating Behaviors, vol. 3, no. 4, pp. 307-323, 2003.

[83] A. E. Field, C. A. Camargo Jr., C. B. Taylor, C. S. Berkey, S. B. Roberts, and G. A. Colditz, "Peer, parent, and media influences on the development of weight concerns and frequent dieting among preadolescent and adolescent girls and boys," Pediatrics, vol. 107, no. 1, pp. 54-60, 2001.

[84] R. H. Striegel-Moore and A. Kearney-Cooke, "Exploring parents' attitudes and behaviors about their children's physical appearance," International Journal of Eating Disorders, vol. 15, no. 4, pp. 377-385, 1994.

[85] M. H. Thelen and J. F. Cormier, "Desire to be thinner and weight control among children and their parents," Behavior Therapy, vol. 26, no. 1, pp. 85-99, 1995. 
[86] L. Rogers, M. D. Resnick, J. E. Mitchell et al., “The relationship between socioeconomic status and eating-disordered behaviors in a community sample of adolescent girls," International Journal of Eating Disorders, vol. 22, pp. 15-23, 1997.

[87] A. A. Caradas, E. V. Lambert, and K. E. Charlton, "An ethnic comparison of eating attitudes and associated body image concerns in adolescent south African school girl," Journal of Human Nutrition and Dietetics, vol. 14, pp. 111-120, 2001.

[88] A. D. Powell and A. S. Kahn, "Racial differences in women's desires to be thin," International Journal of Eating Disorders, vol. 17, no. 2, pp. 191-195, 1995.

[89] K. J. Flynn and M. Fitzgibbon, "Body images and obesity risk among black females: a review of the literature," Annals of Behavioral Medicine, vol. 20, no. 1, pp. 13-24, 1998.

[90] R. M. Gardner, B. N. Friedman, and N. A. Jackson, "Body size estimations, body dissatisfaction, and ideal size preferences in children six through thirteen," Journal of Youth and Adolescence, vol. 28, no. 5, pp. 603-618, 1999.

[91] H. Bruch, "Developmental considerations on anorexia nervosa and obesity," Canadian Journal of Psychiatry, vol. 26, no. 4, pp. 212-217, 1981.

[92] L. Kann, S. A. Kinchen, B. I. Williams et al., "Youth risk behavior Surveillance-United States, 1997," Journal of School Health, vol. 68, no. 9, pp. 355-369, 1998.

[93] “The 2013 Vermont Youth Risk Behavior Survey," http:// healthvermont.gov/research/yrbs/2013/documents/2013_yrbs_ full_report.pdf.

[94] A. M. Gustafson-Larson and R. D. Terry, "Weight-related behaviors and concerns of fourth-grade children," Journal of the American Dietetic Association, vol. 92, no. 7, pp. 818-822, 1992.

[95] L. J. Heinberg, "Theories of body image disturbance: perceptual, developmental and sociocultural models," in Body Image, Eating Disorders and Obesity, K. Thompson, Ed., pp. 27-47, American Psychological Association, Washington, DC, USA, 1996.

[96] C. V. Wiseman, J. J. Gray, J. E. Mosimann, and A. H. Ahrens, "Cultural expectations of thinness in women: an update," International Journal of Eating Disorders, vol. 11, no. 1, pp. 8589, 1992.

[97] S. A. Washi and M. B. Ageib, "Poor diet quality and food habits are related to impaired nutritional status in 13- to 18-year-old adolescents in Jeddah," Nutrition Research, vol. 30, no. 8, pp. 527-534, 2010.

[98] R. C. Adamson, N. Crombie, and T. Kirk, "A critique of the effects of snacking on body weight status," European Journal of Clinical Nutrition, vol. 50, no. 12, pp. 779-783, 1996.

[99] M. P. Levine and K. Harrison, "The role of mass media in the perpetuation and prevention of negative body image and disordered eating," in Handbook of Eating Disorders and Obesity, J. K. Thompson, Ed., pp. 695-717, John Wiley, New York, NY, USA, 2003.

[100] A. Nishina, N. Y. Ammon, A. D. Bellmore, and S. Graham, "Body dissatisfaction and physical development among ethnic minority adolescents," Journal of Youth and Adolescence, vol. 35, no. 2, pp. 179-191, 2006.

[101] A. E. Becker, K. E. Fay, J. Agnew-Blais, A. N. Khan, R. H. Striegel-Moore, and S. E. Gilman, "Social network media exposure and adolescent eating pathology in Fiji," British Journal of Psychiatry, vol. 198, no. 1, pp. 43-50, 2011.

[102] M. Tiggemann and A. S. Pickering, "Role of television in adolescent women's body dissatisfaction and drive for thinness," International Journal of Eating Disorders, vol. 20, no. 2, pp. 199203, 1996.
[103] K. Harrison, "Ourselves, our bodies: thin-ideal media, selfdiscrepancies, and eating disorder symptomatology in adolescents," Journal of Social and Clinical Psychology, vol. 20, no. 3, pp. 289-323, 2001.

[104] G. Cafri, Y. Yamamiya, M. Brannick, and J. K. Thompson, "The influence of sociocultural factors on body image: a metaanalysis," Clinical Psychology: Science and Practice, vol. 12, no. 4, pp. 421-433, 2005.

[105] H. A. Hausenblas, A. Campbell, J. E. Menzel, J. Doughty, M. Levine, and J. K. Thompson, "Media effects of experimental presentation of the ideal physique on eating disorder symptoms: a meta-analysis of laboratory studies," Clinical Psychology Review, vol. 33, no. 1, pp. 168-181, 2013.

[106] D. Clay, V. L. Vignoles, and H. Dittmar, "Body image and self-esteem among adolescent girls: testing the influence of sociocultural factors," Journal of Research on Adolescence, vol. 15, no. 4, pp. 451-477, 2005.

[107] A. E. Field, S. B. Austin, C. A. Camargo Jr. et al., "Exposure to the mass media, body shape concerns, and use of supplements to improve weight and shape among male and female adolescents," Pediatrics, vol. 116, no. 2, pp. e214-e220, 2005.

[108] L. J. Hofschire and B. S. Greenberg, "Media's impact on adolescents' body dissatisfaction," in Sexual Teens, Sexual Media, J. D. Brown, J. R. Steele, and K. Walsh-Childers, Eds., pp. 125-149, Lawrence Erlbaum, Mahwah, NJ, USA, 2001.

[109] D. C. Jones, T. H. Vigfusdottir, and Y. Lee, "Body image and the appearance culture among adolescent girls and boys: an examination of friend conversations, peer criticism, appearance magazines, and the internalization of appearance ideals," Journal of Adolescent Research, vol. 19, no. 3, pp. 323-339, 2004.

[110] D. L. G. Borzekowski, S. Schenk, J. L. Wilson, and R. Peebles, "E-Ana and e-Mia: a content analysis of pro-eating disorder web sites," The American Journal of Public Health, vol. 100, no. 8, pp. 1526-1534, 2010.

[111] "Obesity, eating disorders, and the media," in Children, Adolescents and the Media, V. C. Strasburger, B. J. Wilson, and A. B. Jordon, Eds., pp. 337-400, Sage, Thousand Oaks, Calif, USA, 2013.

[112] P. Pingali, "Westernisation of Asian Diets and the Transformation of Food Systems: Implications for Research and Policy," 2004, http://www.abengoa.es/export/sites/abengoa corp/resources/pdf/biofuels/Food_prices/1_P_Pingali.pdf.

[113] B. M. Popkin, L. S. Adair, and S. W. Ng, "Global nutrition transition and the pandemic of obesity in developing countries," Nutrition Reviews, vol. 70, no. 1, pp. 3-21, 2012.

[114] N. Vaida, "Prevalence of fast food intake among urban adolescent students," The International Journal of Engineering and Science, vol. 2, pp. 353-359, 2013.

[115] "Working moms spend less time daily on kids' diet, exercise," http://www.sciencedaily.com/releases/2012/08/120827162011 .htm. 


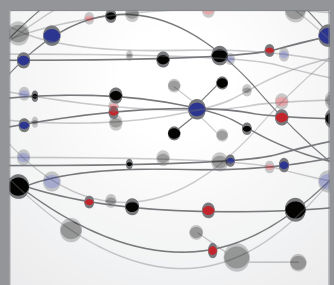

The Scientific World Journal
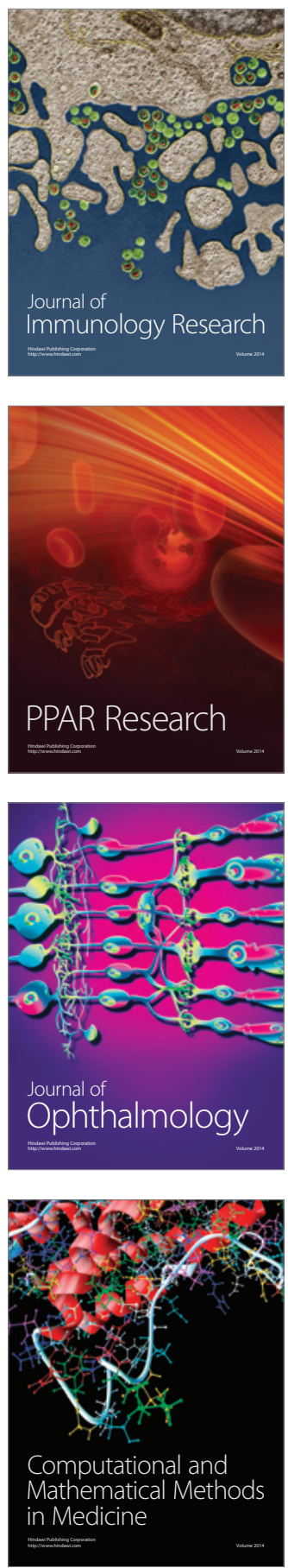

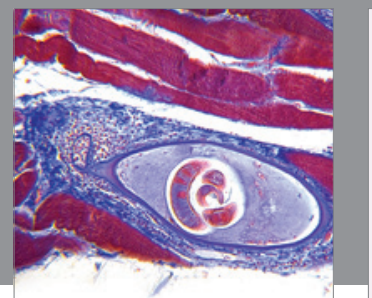

Gastroenterology

Research and Practice
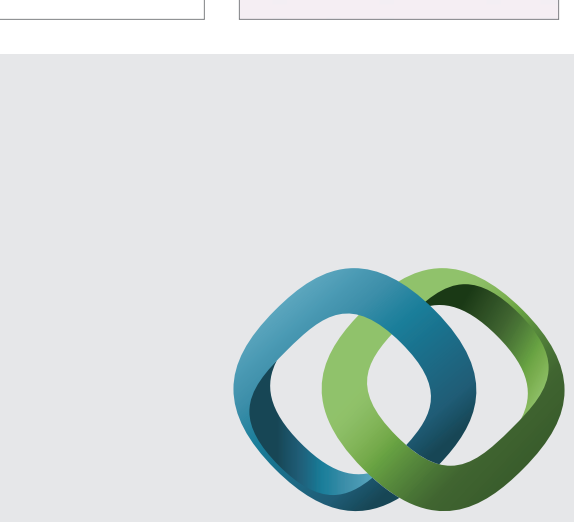

\section{Hindawi}

Submit your manuscripts at

http://www.hindawi.com
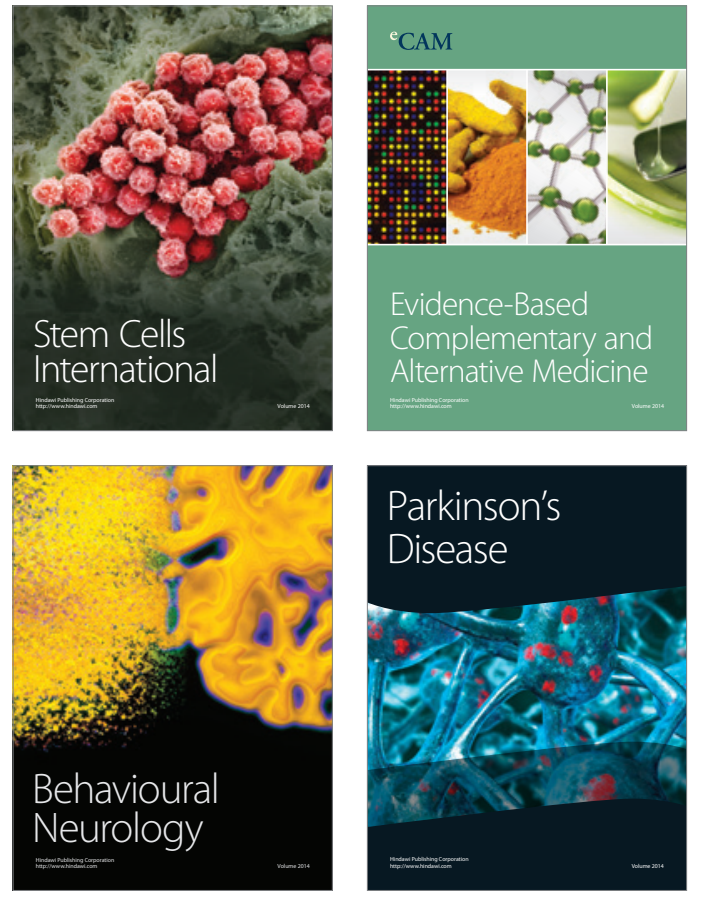
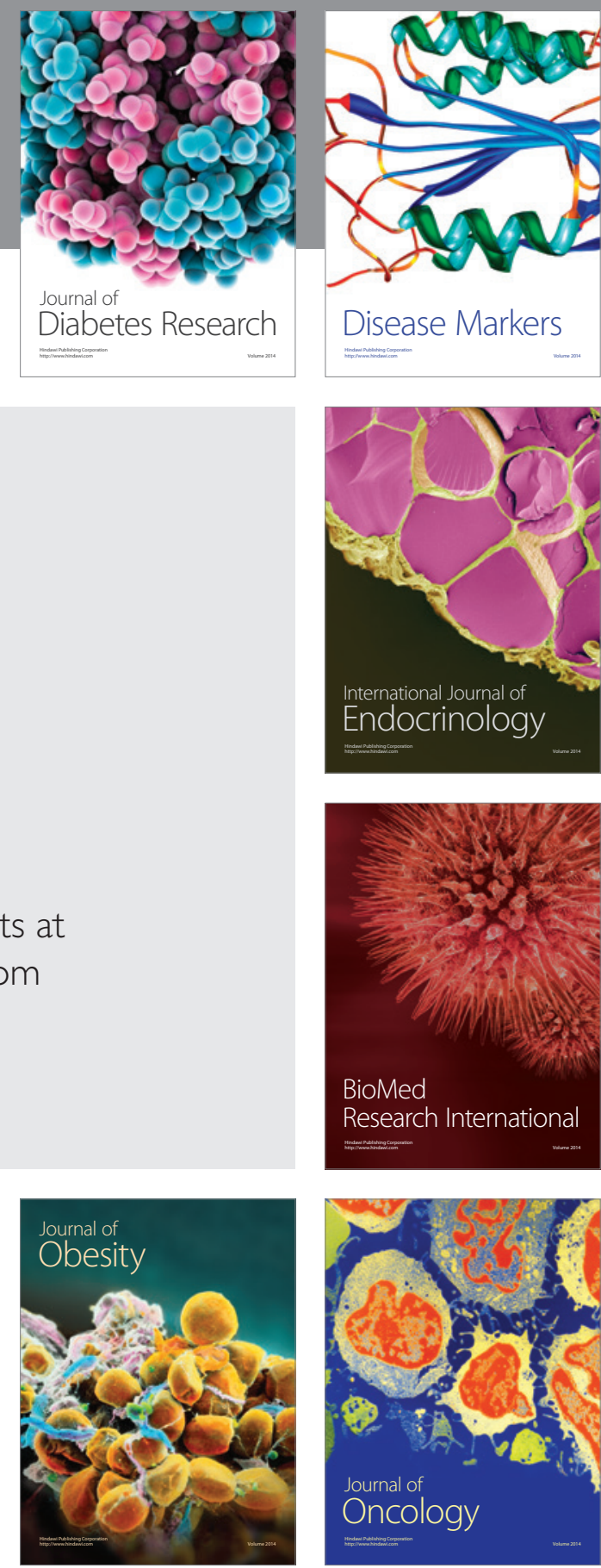

Disease Markers
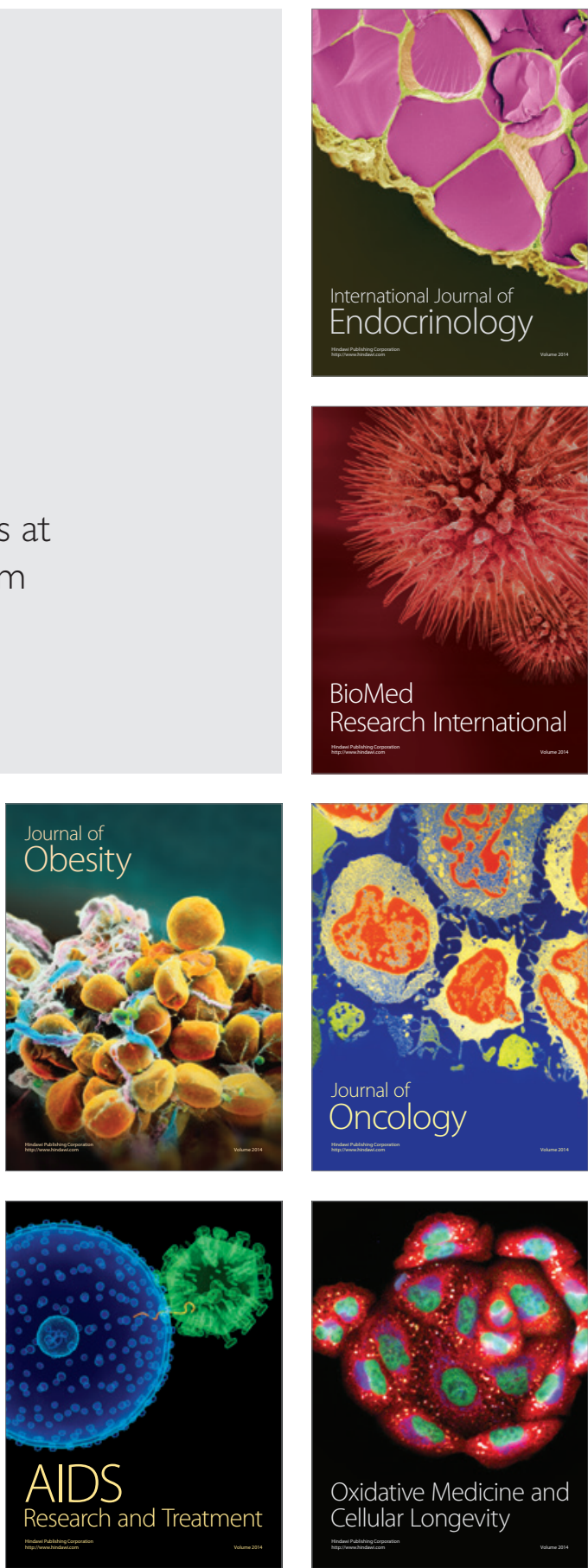